\title{
Pro-apoptotic and Anti-adipogenic Effects of Proso Millet (Panicum miliaceum) Grains on 3T3-L1 Preadipocytes
}

\author{
Do Youn Jun ${ }^{1}$, Ji Young Lee ${ }^{1}$, Cho Rong Han ${ }^{1}$, Kwan-Pil Kim², Myung Chul Seo ${ }^{3}$, Min Hee Nam ${ }^{4}$ \\ and Young $\mathrm{Ho} \mathrm{Kim}{ }^{1 *}$
}

\author{
${ }^{1}$ School of Life Science and Biotechnology, College of Natural Sciences, Kyungpook National University, Daegu 702-701, Korea \\ ${ }^{2}$ Lotte Confectionary Co., LTD, Yangsan 626-120, Korea \\ ${ }^{3}$ Crop Environment Division, NICS, RDA, Suwon 441-857, Korea \\ ${ }^{4}$ Functional Cereal Crop Research Division, NICS, RDA, Miryang 627-803, Korea
}

Received May 20, 2014 /Revised May 24, 2014 /Accepted May 26, 2014

\begin{abstract}
To examine the anti-obese activity of miscellaneous cereal grains, $80 \%$ ethanol extracts from eight selected miscellaneous cereal grains were compared for their cytotoxic effects on 3T3-L1 murine preadipocytes. The ethanol extract of proso millet exhibited the highest cytotoxicity. Further fractionation of the ethanol extract with methylene chloride, ethyl acetate, and n-butanol showed that the cytotoxicity of the ethanol extract was mainly partitioned into the butanol fraction. As compared with differentiated mature adipocytes, 3T3-L1 preadipocytes were more susceptible to the cyctotoxicity of the butanol fraction. When each organic solvent fraction $(25 \mu \mathrm{g} / \mathrm{ml})$ was added during the differentiation period for 6 days, the cell viability was not affected significantly except for the butanol fraction, but the intracellular lipid accumulation declined to a level of $81.5 \% \sim 50.3 \%$ of the control. The Oil Red O staining data also demonstrated that the ethanol extract as well as the butanol fraction could inhibit the differentiation of 3T3-L1 preadipocytes into mature adipocytes. The presence of the butanol extract during the induced adipocytic differentiation also resulted in a significant reduction in the expression levels of critical adipogenesis mediators (C/EBP $\alpha$, PPAR $\gamma, \mathrm{aP} 2$, and LPL) to a barely detectable or undetectable level and the cells retained the fibroblast-like morphology of 3T3-L1. In 3T3-L1 cells, the cytotoxicity of the butanol fraction $(50-100 \mu \mathrm{g} / \mathrm{ml})$ was accompanied by mitochondrial membrane potential $(\Delta \psi \mathrm{m})$ loss, caspase-3 activation, and PARP degradation. Taken together, these results indicate that proso millet grains possess pro-apoptotic and anti-adipocytic activities toward adipocytes, which can be applicable to prevention of obesity.
\end{abstract}

Key words : 3T3-L1 preadipocyte, anti-adipogenesis, anti-obesity, Panicum miliaceum, proso millet

\section{Introduction}

Obesity, which is known to be induced by the imbalance between energy intake and energy expenditure, has been implicated in development of several metabolic diseases including type 2 diabetes, hyperlipidemia, osteoarthritis, sleep apnea, and cardiovascular disease, and cancers [11, 23, 42]. Obesity is mediated by increased adipose tissue mass resulting from increased fat-cell numbers as well as by increased fat-cell size [7]. The number of adipocytes present in an organism is determined by the capacity of the adipogenic proc-

\footnotetext{
*Corresponding author

Tel : +82-53-950-5378, Fax : +82-53-955-5522

E-mail : ykim@knu.ac.kr

This is an Open-Access article distributed under the terms of the Creative Commons Attribution Non-Commercial License (http://creativecommons.org/licenses/by-nc/3.0) which permits unrestricted non-commercial use, distribution, and reproduction in any medium, provided the original work is properly cited
}

ess involving the preadipocyte proliferation (hyperplasia) and their differentiation into mature adipocytes (hypertrophy), whereas the increase of fat-cell size is mainly affected by the amount of lipids accumulated in the adipocytes. The adipose tissue mass can be reduced by the inhibition of adipogenesis from preadipocytes to mature adipocytes, prevention of lipid accumulation in the adipocytes, and induction of apoptosis in adipose cells [33].

In this regard, several naturally occurring phytochemicals from various plant sources, which have potential for inhibiting adipogenesis of preadipocytes and inducing apoptosis of preadipocyte and/or adipocytes, have been reported to possess anti-obesity effects. Polyphenol, coumarin derivatives, carotenoids, and phytoalexins are among the phytochemicals that appear to possess the potential for inhibiting adipogenesis and inducing apoptosis of adipocytes [1, $2,12,13,25,41]$. Because these phytochemicals are also found in plant-derived foods such as fruits, vegetables, 
beans, and grains, much attention has been paid to the health benefits of these foods with respect to their function to lower the incidence of obesity. Furthermore, many studies have reported that a diet rich in whole-grain cereals and their products can exert protective effects against development of obesity, diabetes, cardiovascular disease, and cancers $[3,4,23,34,37]$.

After treatment of 3T3-L1 preadipocytes, derived from a mouse embryo, with a mixture of isobutylmethylxanthine (IBMX), insulin and dexamethasone, the cells can be differentiated into adipocytes along with acquisition of expression of functional differentiation markers, and specific cellular morphology along with an accumulation of lipid droplets within the cells [10]. In this context, 3T3-L1 cells have been used as the in vitro experimental model to mimic adipocyte hyperplasia, to elucidate the mechanism of adipocytic differentiation, and to assess suppressive effects of anti-adipocytic agents $[5,8,33]$.

Agriculture in Korea has traditionally focused on production of the major cereal grains such as rice, barley and wheat, whereas the cultivation and harvesting of other miscellaneous cereal grains has remained in a low level. In recent years, however, due to increased demand for well-being foods, the interest in miscellaneous cereal grains as crude fibers and bioactive phytochemical sources that benefit human health and thus the consumption of miscellaneous cereal grains are also increasing in the developed countries. Although several studies have been performed to extend our understanding on nutritional importance, antioxidant, antimicrobial, antimutagenic, and anticarcinogenic, and antidiabetic properties of miscellaneous cereal grains harvested in Korea [9, 15, 17, 18, 29], the systematic study on their bioactive components associated with the anti-obese efficacy is still rare. If miscellaneous cereal grains are proven as a proper source of anti-obese phytochemicals, it is likely that these grains become highly effective in obesity-related chronic diseases by consuming as diet [22, 34, 38].

As an attempt to compare anti-obese effects of eight selected miscellaneous cereal grains (proso millet, hwanggeumchal sorghum, glutinous sorghum, yellow glutinous foxtail millet, green glutinous foxtail millet, golden foxtail millet, barnyard millet, and adlay) harvested in Korea, in the present study, we intended to investigate the anti-adipogenic effects of $80 \%$ ethanol extracts of the individual grains using 3T3-L1 murine preadipocytes. The $80 \%$ ethanol extract of proso millet grains, which appeared to possess the highest cytotoxicity toward 3T3-L1 cells among the selected grains, was sequentially fractionated by methylene chloride, ethyl acetate, and n-butanol. Since the cytotoxicity toward 3T3-L1 cells was mainly detected in the butanol fraction, the anti-adipogenic activity of the butanol fraction has been examined further by investigating not only its inhibitory effect on adipocytic differentiation of 3T3-L1 preadipocytes, but also its pro-apoptotic effect on 3T3-L1 preadipocytes.

\section{Materials and Methods}

Reagents, chemicals, antibodies and culture medium The ECL Western blotting kit was purchased from Amersham (Arlington Height, IL, USA), and Immobilon-P membrane was obtained from Millipore Corporation (Bedford, MA, USA). Anti-caspase-3 and anti-PARP were purchased from Cell Signaling Technology (Beverly, MA, USA), and anti- $\beta$-actin was obtained from Santa Cruz Biotechnology (Santa Cruz, CA, USA). The cell viability assay kit (CellTiter $96{ }^{\circledR}$ Aqueous One Solution Cell Proliferation assay) was purchased from Promega (Madison, WI, USA). 3T3-L1 preadipocytes were purchased from ATCC (Manassas, VA, USA), and cultured in Dulbecco's modified Eagles medium (DMEM) (Hyclone, Gaithersburg, MD, USA) containing $10 \%$ bovine calf serum (BCS) and $100 \mu \mathrm{g} / \mathrm{ml}$ gentamycin. Insulin, IBMX, and dexamethasone were obtained from Sigma Chemical (St. Louis, MO, USA). Cells were cultured at $37^{\circ} \mathrm{C}$ in a humidified $5 \% \mathrm{CO}_{2}$ atmosphere.

\section{Preparation of sample extracts}

Eight miscellaneous cereal grains, including proso millet (polished grains), hwanggeumchal sorghum (unpolished grains), glutinous sorghum (polished grains), yellow glutinous foxtail millet (polished grains), green glutinous foxtail millet (polished grains), golden foxtail millet (unpolished grains), barnyard millet (unpolished grains), and adlay (polished grains) were provided by National Institute of Crop Science, Rural Development Administration, Miryang, Gyeongnam 627-803, Korea. Individual dried grains were milled on a Blender 7012 (Dynamics Corporation, USA), and then extracted with $80 \%$ ethanol for $3 \mathrm{hr}$ at $80^{\circ} \mathrm{C}$ as described elsewhere [28]. The ethanol extract was evaporated, dissolved in water, and then sequentially extracted with methylene chloride, ethyl acetate, and n-butanol. Each organic solvent fractionation was repeated three times. The organic solvent fraction was concentrated by rotary vacuum evapo- 
rator (Heidolph LR 4000, Germany).

\section{Cell viability assay}

Cytotoxic effect of grain extracts on 3T3-L1 cell was analyzed using the cell viability assay kit (CellTiter 96®) Aqueous One Solution Cell Proliferation Assay) containing 3-(4,5-dimethylthiazol-2-yl)-5-(3-carboxymethoxyphenyl)2-(4-sulfophenyl)-2H-tetrazolium (MTS) reagent. Briefly, 3T3-L1 cells $\left(1 \sim 3 \times 10^{4} /\right.$ well $)$ were cultured with serial dilutions of proso millet extract in 96-well plate. At $48 \mathrm{hr}$ after incubation, the medium was removed and replaced with 100 $\mu \mathrm{l}$ fresh culture media and $10 \mu \mathrm{l}$ MTS solution (Promega, Mdadison, WI, USA). After incubation for an additional 2 h, $25 \mu 1$ 10\% sodium dodecyl sulfate (SDS) was added as a stop solution. The absorbance was measured at $490 \mathrm{~nm}$ by a plate reader to determine the formazan concentration, which reflects the cell viability.

\section{Quantification of lipid content}

Lipid (triglyceride) content was determined using the AdipoRed $^{\mathrm{TM}}$ assay reagent (Cambrex Bio Science Walkersville, Walkersville, MD, USA) according to manufacturer's instructions. Briefly, 3T3-L1 cells $\left(1 \times 10^{4} /\right.$ well $)$ were seeded in 96-well microtiter plates and treated for induction of adipocytic differentiation. On day 6 after induction, the cells were washed with PBS and $100 \mu \mathrm{l}$ of PBS was added to the wells. Five microliter of AdipoRed ${ }^{\mathrm{TM}}$ assay reagent was added to each well and incubated for $10 \mathrm{~min}$ at RT. The amount of triglyceride was determined by measuring with an excitation wave/length of $485 \mathrm{~nm}$ and emission wave/length of $572 \mathrm{~nm}$ using PerkinElmer ${ }^{\mathrm{TM}}$ Walac Victor 3.

\section{Induction of adipocytic differentiation and oil droplet staining}

The 3T3-L1 murine preadipose cell line was purchased from American Type Culture Collection (Manassas, VA, USA). Adipocytic differentiation of 3T3-L1 preadipocytes was induced as previously described [13]. Briefly, cells were cultured in Dulbecco's modified Eagles medium (DMEM) containing $10 \%$ bovine calf serum (BCS) and $100 \mu \mathrm{g} / \mathrm{ml}$ of gentamycin until confluent. Two days after confluence (day 0 , D0), the differentiation of cells were stimulated with DMEM containing 10\% fetal bovine serum (FBS), $167 \mathrm{nM}$ insulin, $0.5 \mathrm{mM} \mathrm{IBMX}$, and $1 \mu \mathrm{M}$ dexamethasone for 2 days (day 2, D0 D2). On day 2, the media was changed with DMEM/10\% FBS containing $100 \mathrm{nM}$ insulin and was in- cubated for two days (day 4, D2 D4), followed by culturing with DMEM/10\% FBS for 2 additional days (day 6, D4 D6). Grain extracts were administered during indicated time periods of the adipocytic differentiation. For Oil Red O staining, on day 6, the accumulated lipid droplet within the cells was stained with Oil Red O Dye using the Adipogenesis assay kit (Cayman Chemical Company, Ann Arbor, MI, USA) according to manufacturer's instructions. 3T3-L1 preadipocytes were used at passage 3 through 9 of cells for all experiments.

\section{Total RNA isolation and RT-PCR}

Cells were washed twice in PBS, then total RNA was isolated using the Trizol reagent from Invigtrogen (Carlsbad, CA, USA) according to the manufacturer's instructions and DNase I treatment. After RNA quantification by GE NanoVue Spectrophotometer (GE healthcare, Buckinghamshire, UK), 1 ug RNA was reverse transcribed using First strand cDNA synthesis kit (Thermo scientific, Logan, UT, USA) for cDNA synthesis. GAPDH was amplified with forward (5'-ATCCTGCGTCTGGACCTGGCT-3') and reverse (5'-CTGATCCACATCTGCTGGAAG-3') primers. Primers used in the PCR were as follows: CCAAT/enhancer binding protein-alpha $(C E B P / \alpha)$ forward, (5'-GTGGACAAGAACAGCAACGA-3') and reverse, (5'-GGTCAACTCCAGCACCTTCT-3'); peroxisome proliferator-activated receptor gam-

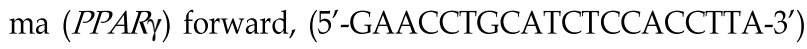
and reverse, (5'-TTCAGCTTGAGCTGCAGTTC - $\left.3^{\prime}\right)$; adipocyte protein 2 (aP2) forward, (5'-TCACCTGGAAGACAGCTCCT-3') and reverse, (5'-ACTCTCTGACCGGATGGTGA-3'); lipoprotein lipase (LPL) forward, (5'GACTGAGGATGGCAAGCAAC-3') and reverse, (5'-CAGTTCTCCGATGTCCACCT $\left.-3^{\prime}\right)$.

\section{Preparation of cell lysate and western blot analysis}

Cellular lysates were prepared by suspending cells $(5 \times$ $\left.10^{6}\right)$ in $300 \mu$ of lysis buffer $(137 \mathrm{mM} \mathrm{NaCl}, 15 \mathrm{mM}$ EGTA, $1 \mathrm{mM}$ sodium orthovanadate, $15 \mathrm{mM} \mathrm{MgCl}, 25 \mathrm{mM}$ MOPS, $1 \mathrm{mM}$ PMSF, and $2.5 \mathrm{~g} / \mathrm{ml}$ proteinase inhibitor E-64, 0.1\% Triton $\mathrm{X}-100, \mathrm{pH}$ 7.2). The cells were disrupted by sonication and extracted at $4^{\circ} \mathrm{C}$ for $30 \mathrm{~min}$. An equivalent amount of protein lysate $(25 \mu \mathrm{g})$ was electrophoresed on $4 \sim 12 \%$ NuPAGE gradient gel (Invitrogen/Novex, Carlsbad, CA, USA) with MOPS buffer and then electrotransferred to Immobilon-P membranes. Detection of each protein was performed using the ECL Western blotting kit following the 
manufacturer's instructions.

\section{Statistical analysis}

Unless otherwise indicated, each result in this paper is representative of at least three separate experiments. Values represent the mean \pm standard deviation (SD) of these experiments. The statistical significance was calculated with Student's $t$-test. $P$ values less than 0.05 were considered significant.

\section{Results and Discussion}

Cytotoxic effect of the $80 \%$ ethanol extracts and their solvent fractions obtained from eight selected miscellaneous cereal grains on viability of $3 T 3$ preadipocytes

To evaluate anti-adipogenic properties of miscellaneous cereal grains, which were harvested in Korea, including proso millet, hwanggeumchal sorghum, glutinous sorghum, yellow glutinous foxtail millet, green glutinous foxtail millet, golden foxtail millet, barnyard millet, and adlay, the inhibitory effect of $80 \%$ ethanol extracts prepared from the individual grains on the viability of 3T3-L1 preadipocytes was measured using MTS assay. As shown in Table 1, the presence of $80 \%$ ethanol extract $(100 \mu \mathrm{g} / \mathrm{ml})$ of proso millet, yellow glutinous foxtail millet, barnyard grass millet, or adlay appeared to reduce the viability of 3T3-L1 cells to a level of $65.3 \pm 0.01 \%, 74.2 \pm 0.02 \%, 69.7 \pm 0.03 \%, 80.1 \pm 0.01 \%$, or $81.0 \pm 0.03 \%$, respectively. These results show that the $80 \%$ ethanol extract of proso millet grains exhibited the highest cytotoxicity followed by those of golden foxtail millet grains,

Table 1. Cytotoxic effect of $80 \%$ ethanol extract of eight miscellaneous cereal grains on 3T3-L1 preadipocytes

\begin{tabular}{lc}
\hline \multirow{2}{*}{ Miscellaneous cereal grains } & $80 \%$ ethanol extract \\
\cline { 2 - 2 } & Cytotoxicity $^{*}$ \\
\hline Proso millet & $65.3 \pm 0.01$ \\
Hwanggeumchal sorghum & $107.9 \pm 0.05$ \\
Glutinous sorghum & $98.1 \pm 0.08$ \\
Yellow glutinous foxtail millet & $74.2 \pm 0.02$ \\
Green glutinous foxtail millet & $86.3 \pm 0.04$ \\
Golden foxtail millet & $69.7 \pm 0.03$ \\
Barnyard millet & $80.1 \pm 0.01$ \\
Adlay & $81.0 \pm 0.03$ \\
\hline
\end{tabular}

* After 3T3-L1 cells $\left(1 \times 10^{4} /\right.$ well $)$ were treated with each sample in 96-well plate for $48 \mathrm{hr}$, cell viability was determined by the MTS coloimetric assay. Each value is expressed as mean $\pm \mathrm{SD}$ ( $\mathrm{n}=3$ with six replicates per independent experiment). and yellow glutinous foxtail millet grains.

Although proso millet (Panicum miliaceum L.) is one of the oldest cereal crop used for humans in Asia and Africa [21], pharmaceutical studies on the health benefits of proso millet grains are not well-established. In the nutritional aspects, the proso millet grains are known to be relatively rich in protein, mineral substances, and vitamins, when compared with common cereal grains [14]. In the physiological and functional aspects, it has been reported that the extract of proso millet possesses anti-oxidant activity [6], hepatic protective activity [26], anti-diabetic and anti-hyperlipidemic effects $[29,31]$, anti-inflammatory activity [30], and a beneficial influence on metabolism of cholesterol and lipid [27, 36]. With respect to anti-obese effect of proso millet grains, the aqueous extract of proso millet grains has recently been shown to down-regulate the expression level of adipogenic transcription factors [32]. However, little information has been known regarding the involvement of apoptotic cell death in the anti-obesity effect of proso millet grains.

To examine further the anti-adipogenic property of proso millet grains, the $80 \%$ ethanol extract of proso millet grains was sequentially fractionated with methylene chloride, ethyl acetate and n-butanol, and then individual fractions were tested for their inhibitory effects on the viability of 3T3-L1 preadipocytes or mature adipocytes that could be obtained from induced adipocytic differentiation of 3T3-L1 cells by exposure to the mixture of $167 \mathrm{nM}$ insulin, $0.5 \mathrm{mM}$ IBMX, and $1 \mu \mathrm{M}$ dexamethasone for 6 days. When 3T3-L1 preadipocytes were treated with the ethanol extract at a concentration of $25 \mu \mathrm{g} / \mathrm{ml}, 50 \mu \mathrm{g} / \mathrm{ml}$, or $100 \mu \mathrm{g} / \mathrm{ml}$, the cell viability appeared to decline to a level of $80.2 \%, 77.5 \%$ or $68.0 \%$, respectively (Fig. 1A). In addition, the cytotoxicity of the $80 \%$ ethanol extract of proso millet grains toward 3T3-L1 preadipocytes appeared to be mainly partitioned into the butanol fraction. Treatment of 3T3-L1 cells with the butanol fraction at a concentration of $25 \mu \mathrm{g} / \mathrm{ml}, 50 \mu \mathrm{g} / \mathrm{ml}$, or $100 \mu \mathrm{g} / \mathrm{ml}$ resulted in a reduction in cell viability to a level of $63.2 \%$, $34.3 \%$ or $30.0 \%$, respectively. As shown in Fig. 1B, the mature adipocytes appeared to be less sensitive to the cytotoxicity of the butanol fraction compared with 3T3-L1 preadipocytes, and the viability of the mature adipocytes was sustained up to a level of $80.0 \%$ in the presence of the butanol fraction $(100 \mu \mathrm{g} / \mathrm{ml})$. Consequently, these results show that among the eight selected miscellaneous cereal grains, the proso millet grains possessed the highest cytotoxicity toward 3T3-L1 preadipocytes, and the cytotoxicity was more 

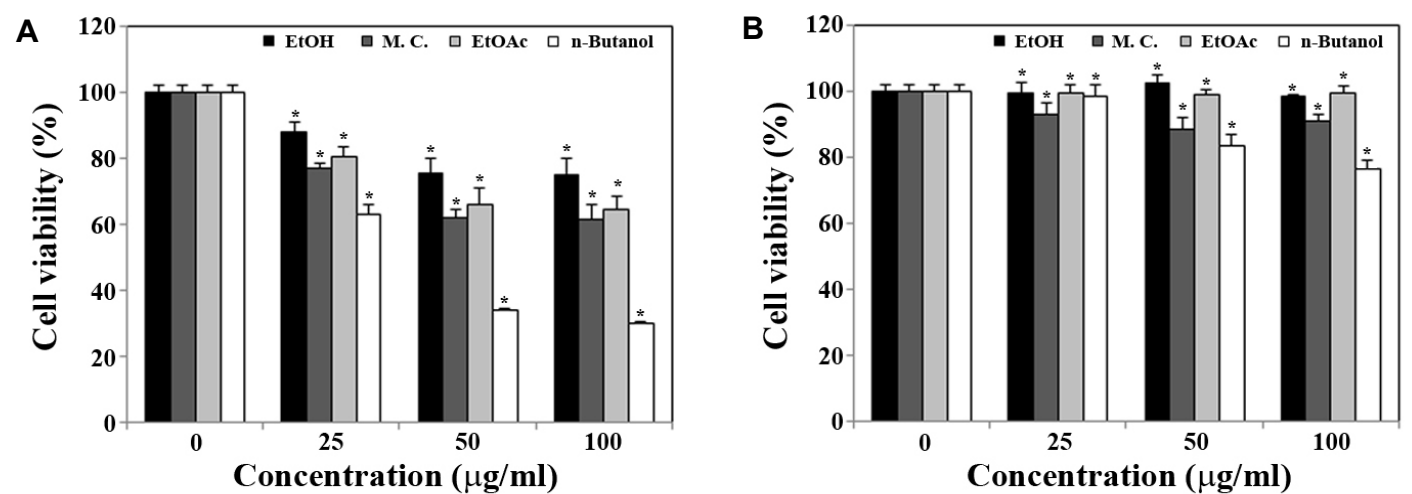

Fig. 1. Effect of $80 \%$ ethanol extract and its organic solvent fractions of proso millet grains on cell viability of 3T3-L1 preadipocyes (A) and mature adipocytes (B). 3T3-L1 preadipocytes and mature adipocytes obtained from induced differentiation of 3T3-L1 cells by standard procedures as described in Materials and Methods were treated with $80 \%$ ethanol extract, or subsequent four organic solvent fraction (methylene chloride, ethyl acetate, or n-butanol) of proso millet grains at various concentrations (vehicle, $25 \mu \mathrm{g} / \mathrm{ml}, 50 \mu \mathrm{g} / \mathrm{ml}$, and $100 \mu \mathrm{g} / \mathrm{ml}$ ). After individual cells $\left(1 \times 10^{4} /\right.$ well) were treated with each sample in 96-well plate for $48 \mathrm{hr}$, cell viability was determined by the MTS coloimetric assay. Each value is expressed as mean \pm SD (n=3 with six replicates per independent experiment). ${ }^{*} p<0.05$ compared to control.

effective on 3T3-L1 preadipocytes than on the mature adipocytes which could be obtained from induced differentiation of 3T3-L1 cells.

Inhibitory effect of the butanol fraction of proso millet grains on adipocytic differentiation of $3 T 3-L 1$ preadipocytes

Previously, it has been reported that a reduction in the adipose tissue mass in the body can be mediated by various approaches, such as inhibiting adipogenesis from preadipocytes to mature adipocytes, preventing lipid accumulation in the adipocytes, and inducing apoptosis in adipose cells [33]. Because current results showed that the ethanol extract or the butanol fraction of proso millet grains could exert a potent cytotoxicity toward 3T3-L1 preadipocytes, it was likely that that proso millet grains might possess a potential benefit to reduce the number of adipocytes.

We next decided to examine whether the ethanol extract and organic solvent fractions from proso millet grains can suppress the induced differentiation of 3T3-L1 preadipocytes to adipocytes at a low dosage, which is insufficient to exert cytotoxicity. In this regard, 3T3-L1 cells were continuously exposed to the ethanol extract, methylene chloride fraction, ethyl acetate fraction, or $\mathrm{n}$-butanol fraction at a concentration of $25 \mathrm{\mu g} / \mathrm{ml}$ during the differentiation period for 6 days, and then cell viability and intracellular lipid accumulation were measured. As shown in Fig. 2A and 2B, although the presence of each fraction at a concentration of $25 \mu \mathrm{g} / \mathrm{ml}$, except for the butanol fraction, during the differentiation pe- riod for 6 days did not influence significantly the cell viability, it could reduce the intracellular lipid accumulation to a level of $81.5 \% \sim 50.3 \%$ of the control. Under these conditions, the Oil Red O staining, which was performed to visualize intracellular lipid accumulation during the induced adipocytic differentiation of 3T3-L1 cells [5, 13], showed that the presence of the butanol fraction during the 6-day differentiation period caused not only almost complete prevention of intracellular lipid accumulation, but also retaining of fibroblast-like morphology of 3T3-L1 preadipocytes (Fig. 2C). These Oil Red O staining data confirmed the inhibitory effect of the butanol fraction on differentiation of 3T3-L1 preadipocytes into mature adipocytes.

To examine the mechanism underlying the inhibitory effect of the butanol fraction on the induced differentiation of 3T3-L1 preadipocytes to mature adipocytes, 3T3-L1 preadipocytes were stimulated to induce differentiation for 6 days, during which periods the cells were exposed to the butanol extract $(25 \mu \mathrm{g} / \mathrm{ml})$ for 2 days at various time points (D0-D2, D2-D4 or D4-D6). Under these conditions, the expression levels of CCAAT/enhancer binding protein-alpha $(\mathrm{C} / \mathrm{EBPa})$ and peroxisome proliferator-activated receptorgamma (PPARy), which are known to be crucial transcription factors required for adipocytic differentiation $[5,19$, 33], and the endogenous gene expression of transcriptional targets of PPAR $\gamma$, such as aP2 and LPL [40], were investigated by RT-PCR method. During the induced adipocytic differentiation of 3T3-L1 preadipocytes for 6 days, the expression level of C/EBPa and PPARy became gradually 
A

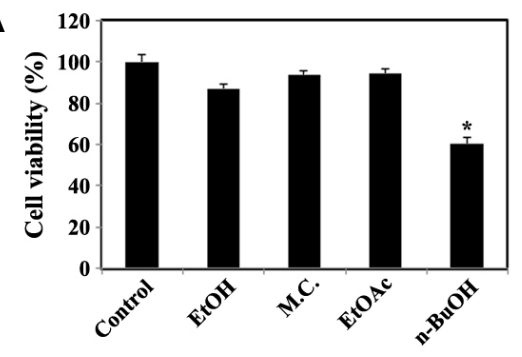

C

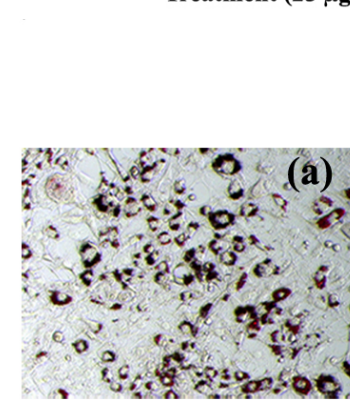

B

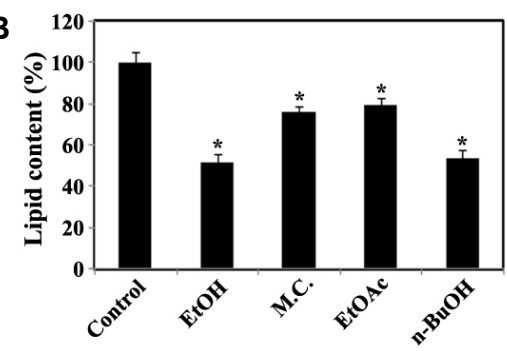

Treatment $(25 \mu \mathrm{g} / \mathrm{ml})$
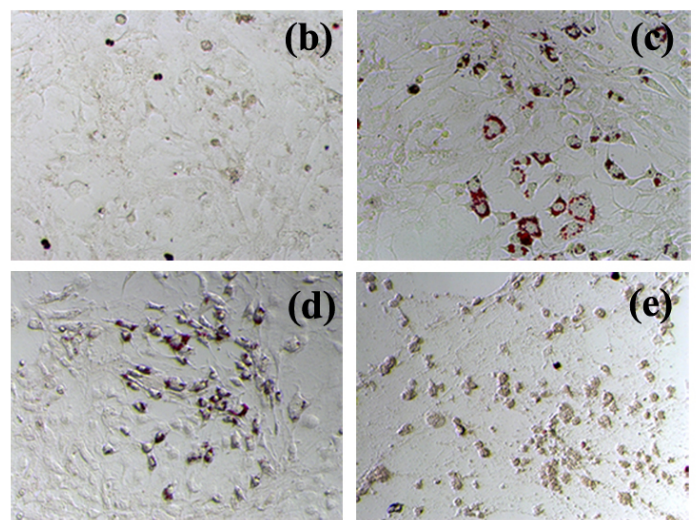

Fig. 2. Effect of $80 \%$ ethanol extract and its organic solvent fractions of proso millet grains on cell viability (A) and intracellular lipid accumulation (B and C) during adipocytic differentiation of 3T3 L1. Inhibitory effect of presence of $25 \mu \mathrm{g} / \mathrm{ml}$ of various extracts of proso millet grains during induced adipocytic differentiation of 3T3-L1 preadipocytes for 6 days on cell viability (A), intracellular lipid accumulation (B and C). Cell viability was determined by the MTS colorimetric assay, and intracellular lipid content was measured by using the AdipoRed Assay ${ }^{\mathrm{TM}}$ reagent as described in Materials and Methods. Each value is expressed as mean $\mathrm{SD}$ ( $\mathrm{n}=3$ with six replicates per independent experiment). ${ }^{*} p<0.05$ compared with control. On day 6, cells were stained with Oil Red O dye to visualize the accumulated lipid droplet. A representative study is shown and two additional experiments yielded similar results. Control cells (a). Cells treated with $80 \%$ ethanol extract (b), methylene chloride fraction (c), ethyl acetate fraction (d), or n-butanol fraction (e).

up-regulated (Fig. 3A). At the same time, however, the presence of the butanol extract during the induced adipocytic differentiation resulted in a significant reduction in the expression levels of $\mathrm{C} / \mathrm{EBPa}, \mathrm{PPAR} \gamma, \mathrm{aP} 2$, and LPL to a barely detectable or undetectable level (Fig. 3B). In particular, the suppressive effect of the butanol extract $(25 \mu \mathrm{g} / \mathrm{ml})$ on the expression level of $\mathrm{C} / \mathrm{EBPa}$ appeared to be more significant if the butanol fraction was added at the early stage (D0-D2) of the differentiation period. These results indicated that the butanol fraction of proso millet could suppress differentiation of 3T3-L1 preadipocytes into mature adipocytes and suggest that down-regulation of expression levels of the transcription factors such as $\mathrm{C} / \mathrm{EBPa}$, and PPAR $\gamma$ was associated with the butanol fraction-induced suppression of adipocytic differentiation.

Apoptogenic effect of the butanol fraction of proso millet grains on 3T3-L1 preadipocytes

Because the induction of apoptosis in adipose cells can lead to their own destruction into apoptotic bodies which are cleared by surrounding phagocytic cells without inducing a local damaging inflammatory response [16, 35], apoptosis is considered as an efficient mechanism by which adipose cells can be removed upon treatment with anti-obesity drugs.

In order to examine whether the cytotoxic effect of the butanol fraction on 3T3-L1 cells was responsible to induced apoptotic cell death, several apoptotic events including induction of apoptotic sub- $\mathrm{G}_{1}$ peak, mitochondrial membrane potential $(\Delta \psi \mathrm{m})$ loss, activation of caspase-3, and cleavage of poly (ADP-ribose) polymerase (PARP) into two fragments were investigated. When 3T3-L1 cells were treated with 0.1 $\%$ DMSO (vehicle) or the butanol fraction $(25 \mu \mathrm{g} / \mathrm{ml}, 50 \mu \mathrm{g} /$ $\mathrm{ml}$, and $100 \mu \mathrm{g} / \mathrm{ml}$ ) for $24 \mathrm{hr}$, the ratio of negative fluorescence at concentrations of $25 \mu \mathrm{g} / \mathrm{ml}, 50 \mu \mathrm{g} / \mathrm{ml}$, and 100 $\mu \mathrm{g} / \mathrm{ml}$ of the butanol fraction were $26.7 \%, 41.8 \%$ and $44.6 \%$, respectively (Fig. $4 \mathrm{~A}$ ), suggesting that mitochondrial damage causing $\Delta \psi m$ loss was induced in a dose-dependent manner. 

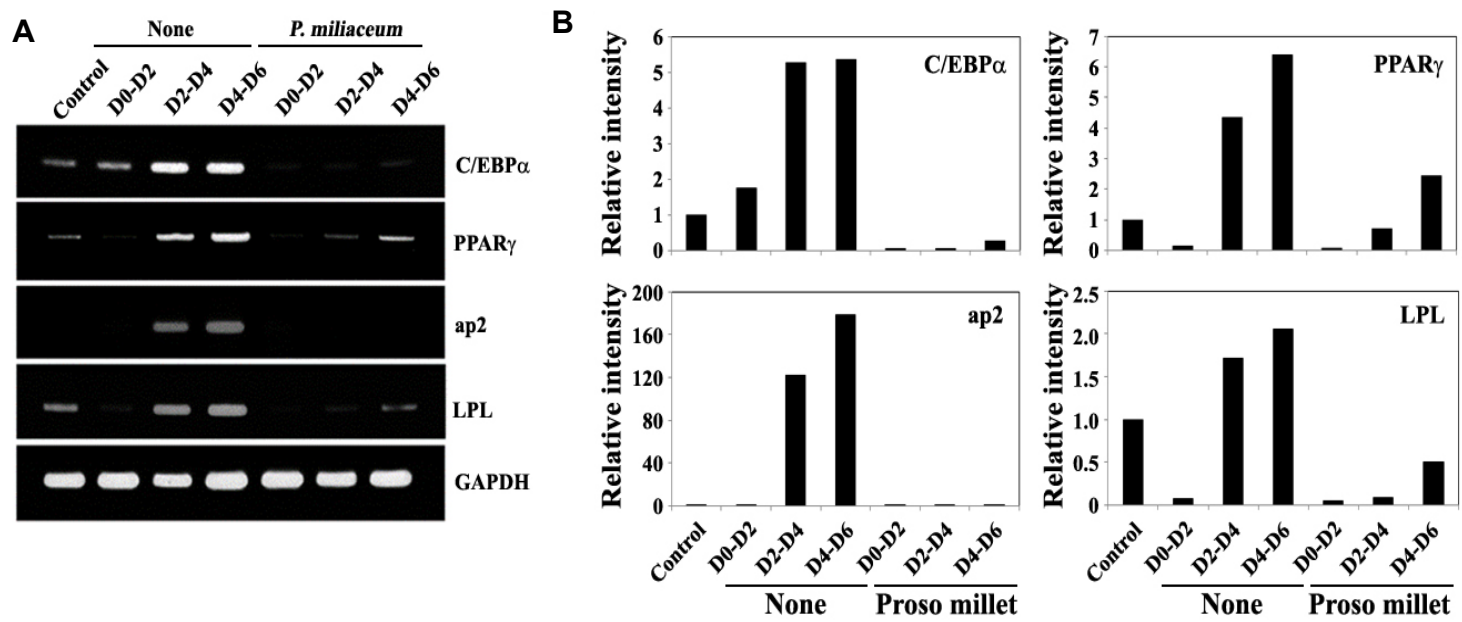

Fig. 3. Effect of the butanol extract of proso millet grains on the expression level of transcription factors such as $C / E B P \alpha$ and PPAR $\gamma$ during the early (D0-D2), intermediate (D2-D4) and late stage (D4-D6) of adipocytes differentiation. 3T3L1 preadipocytes were induced to differentiate according to the standard procedures in Material and Methods. The butanol fraction $(25 \mu \mathrm{g} / \mathrm{ml})$ was added during the days $0-2,2-4$, or $4-6$ of the 6-day differentiation periods. On day 6, mRNAs were prepared and cDNAs were synthesized as described in Materials and Methods. The expression level of C/EBP $\alpha, \mathrm{PPAR} \gamma, \mathrm{aP} 2$ and Lpl was determined by RT-PCR. The synthesized cDNA was subjected to RT-PCR with specific primers to amplify the target genes and the PCR products were resolved on a 1.5\% agarose gel electrophoresis. A representative study is shown and two additional experiments yielded similar results.

In addition, western blot analysis revealed that while there was no detectable active caspase-3 $(17 \mathrm{kDa})$ in 3T3-L1 cells treated with vehicle, the cleavage of procaspase-3 $(32 \mathrm{kDa})$ into active form $(17 \mathrm{kDa})$ was detected in 3T3-L1 cells after treatment with the butanol fraction $(50 \mathrm{\mu g} / \mathrm{ml})$ in a time-dependent manner (Fig. 4B).

Previously, it has been reported that mitochondrial damage causing $\Delta \psi m$ loss and cytochrome c release into cyto- plasm are frequently involved in chemical induced apoptotic signaling pathways as early pro-apoptotic events [24, 39], and resultant activation of caspase cascade including capase-3, leading to cleavage of PARP. As the downstream events of $\Delta \psi \mathrm{m}$ loss, the activation of caspase-3 and PARP cleavage were provoked in 3T3-L1 cells treated with the butanol extract $(50 \mathrm{\mu g} / \mathrm{ml})$ in a time-dependent manner. The cleavage of PARP into two fragments by active caspse- 3 has

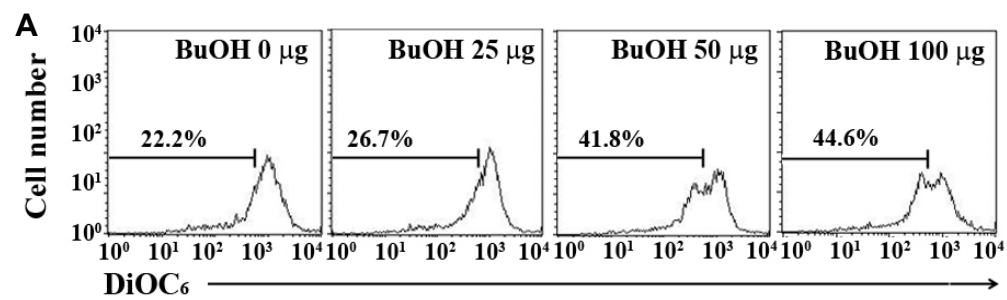

B

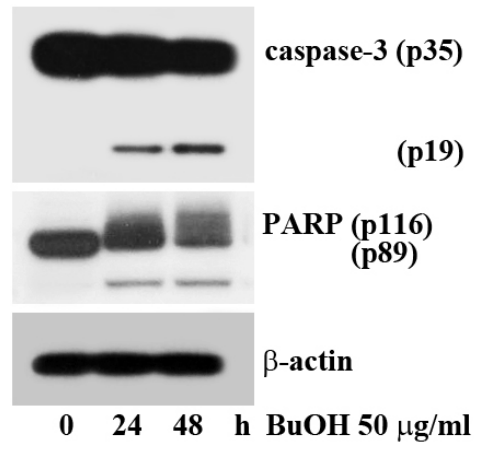

Fig. 4. Effect of the butanol extract of proso millet grains on the mitochondrial membrane potential (A), and kinetic analysis of activation of caspases cascade and PARP degradation (B) in 3T3-L1. To measure the changes in the mitochondrial membrane potential, 3T3-L1 cells were treated with vehicle, $25 \mu \mathrm{g} / \mathrm{ml}, 50$ $\mu \mathrm{g} / \mathrm{ml}$, and $100 \mu \mathrm{g} / \mathrm{ml}$ of the butanol extract for $24 \mathrm{hr}$, stained with $\mathrm{DiOC}_{6}$ and subjected to flow cytometric analysis. After cells were treated with $50 \mu \mathrm{g} / \mathrm{ml}$ of the butanol extract for $48 \mathrm{hr}$, cell lysates were prepared as described in Materials and Methods. For western blot analysis, 4-12\% SDS gradient polyacrlyamide gels and electrotransferred to Immobilon-p membrane. Western blot analysis was performed using ECL western blotting detection system. A representative study is shown and two additional experiments yielded similar results. 
been proposed as a marker of apoptosis in many experimental models [20]. Consequently, current results demonstrated that the cytotoxic effect of the butanol fraction toward 3T3-L1 was attributable to apoptotic cell death mediated by $\Delta \psi m$ loss and subsequent activation of caspase-3 and cleavage of PARP.

In conclusion, this is the first report to demonstrate that the butanol fraction obtained from $80 \%$ ethanol extract of proso millet (Panicum miliaceum) grains exerts cytotoxicity, which is attributable to inducing apoptotic cell death, in 3T3-L1 preadipocytes and inhibits terminal differentiation of 3T3-L1 preadipocytes into mature adipocytes. The results show that the cytotoxic effect of the butanol extract was more dominant on 3T3-L1 preadipocytes than on mature adipocytes. The induced apoptotic cell death appeared to be mediated by mitochondria-dependent activation of caspase-3 and subsequent cleavage of PARP. In addition to induction of apoptosis, the butanol extract $(25 \mu \mathrm{g} / \mathrm{ml})$ could effectively suppress adipocytic differentiation of 3T3-L1 cells, without exerting a significant cytotoxic effect, via down-regulation of the expression level of transcription factors, such as C/EBPa and PPAR 1 1, which are known to be crucial for adipogenesis. These results provide an insight into the mechanism underlying the anti-adipogenic effect of proso millet grains.

\section{Acknowledgements}

This research was carried out with the support of "Cooperative Research Program for Agriculture Science \& Technology Development (Project No. PJ006638)", Rural Development Administration, Republic of Korea.

\section{References}

1. Ambati, S., Yang, J. Y., Rayalam, S., Park, H. J., Della-Fera, M. A. and Baile, C. A. 2009. Ajoene exerts potent effects in 3T3-L1 adipocytes by inhibiting adipogenesis and inducing apoptosis. Phytother Res 23, 513-518.

2. Ahn, J., Lee, H., Kim, S. and Ha, T. 2010. Curcumin-induced suppression of adipogenic differentiation is accompanied by activation of Wnt/beta-catenin signaling. Am J Physiol Cell Physiol 298, 1510-1516.

3. Anderson, J. W. 2003. Whole grains protect against atherosclerotic cardiovascular disease. Proc Nutr Soc 62, 135-142.

4. Awika, J. M. and Rooney, L. W. 2004. Sorghum phytochemicals and their potential impact on human health. Phytochemistry 65, 1199-1221.

5. Camp, H. S., Ren, D. and Leff, T. 2002. Adipogenesis and fat-cell function in obesity and diabetes. Trends $\mathrm{Mol}$ Med 8 , 442-447.

6. Chandrasekara, A. and Shahidi, F. 2010. Content of insoluble bound phenolics in millets and their contribution to antioxidant capacity. J Agric Food Chem 58, 6706-6714.

7. Couillard, C., Mauriege, P., Imbeault, P., Prudhomme, D., Nadeau, A., Tremblay, A., Bouchard, C. and Despres, J. P. 2000. Hyperleptinemia is more closely associated with adipose cell hypertrophy than with adipose tissue hyperplasia. Int J Obes Relat Metab Disord 24, 782 - 788.

8. Gregoire, F. M. 2001. Adipocyte differentiation: from fibroblast to endocrine cell. Exp Biol Med 226, 997-1002.

9. Ha, Y. D. and Lee, S. P. 2001. Characteristics of proteins in Italian millet, sorghum and common millet. Korean $J$ Postharvest Sci Technol 8, 187-192.

10. Hemati, N., Ross, S. E., Erickson, R. L., Groblewski, G. E. and MacDougald, O. A. 1997. Signaling pathways through which insulin regulates ccaat/enhancer binding protein alpha $(\mathrm{C} / \mathrm{EBPa})$ phosphorylation and gene expression in 3T3-L1 adipocytes. Correlation with GLUT4 gene expression. J Biol Chem 272, 25913-25919.

11. Hirahatake, K. M., Slavin, J. L., Maki, K. C. and Adams, S. H. 2014. Associations between dairy foods, diabetes, and metabolic health: potential mechanisms and future directions. Metabolism 63, 618-627.

12. Hirata, T., Fujii, M., Akita, K., Yanaka, N., Ogawa, K., Kuroyanagi, M. and Hongo, D. 2009. Identification and physiological evaluation of the components from citrus fruits as potential drugs for anti-corpulence and anticancer. Bioorg Med Chem 17, 25-28.

13. Jun, D. Y., Han, C. R., Choi, M. S., Bae, M. A., Woo, M. H. and Kim, Y. H. 2011. Effect of mollugin on apoptosis and adipogenesis of 3T3-L1 preadipocytes. Phytother Res 25, 724-731.

14. Kalinova, J. and Moudry, J. 2006. Content and quality of protein in Proso millet (Panicum miliaceum L.) varieties. Plant Foods for Human Nutrition 61, 45-49.

15. Kil, H. Y., Seong, E. S., Ghimire, B. K., Chung, I. M., Kwon, S. S., Goh, E. J., Heo, K., Kim, M. J., Lim, J. D., Lee, D. and Yu, C. Y. 2009. Antioxidant and antimicrobial activities of crude sorghum extract. Food Chem 115, 1234-1239.

16. Kurosaka, K., Takahashi, M., Watanabe, N. and Kobayashi Y. 2003. Silent cleanup of very early apoptotic cells by macrophages. J Immunol 171, 4672-4679.

17. Kwak, C. S., Lim, S. J., Kim, S. A., Park, S. C. and Lee, M. S. 2004. Antioxidative and antimutagenicity effects of Korean buckwheat, sorghum, millet, and Job's tears. $J$ Korean Soc Food Sci Nutr 33, 921-929.

18. Kweon, Y. M. and Park, K. Y. 1998. Antimutagenic and anticarcinogenic effect of sorghum. J Cancer Prev 3, 128-135.

19. Lazar, M. A. 2002. Becoming fat. Gene Dev 16, 1-5.

20. Lazebnik, Y. A., Kaufmann, S. H., Desnoyers, S., Poirier, G. G. and Earnshaw, W. C. 1994. Cleavage of poly (ADP-ribose) polymerase by a proteinase with properties like ICE. Nature 371, 346-347.

21. Lu, H., Zhang, J., Liu, K. B., Wu, N., Li. Y., Zhou, K., Ye., 
M., Zhang, T., Zhang, H., Yang, X., Shen, L., Xu, D. and $\mathrm{Li}$, Q. 2009. Earliest domestication of common millet (Panicum miliaceum) in East Asia extended to 10,000 years ago. Proc Natl Acad Sci USA 106, 7367-7372.

22. Marquart, L., Jacobs, D. R. Jr. and Slavin, J. L. 2000. Whole grains and health. J Am Coll Nutr 19, 289-290.

23. McKeown, N. M., Meigs, J. B., Liu, S., Wilson, P. W and Jacques, P. F. 2002. Whole-grain intake is favorably associated with metabolic risk factors for type 2 diabetes and cardiovascular disease in the framingham offspring study. Am J Clin Nutr 76, 390-398.

24. Nagata, S. 1997. Apoptosis by death factor. Cell 88, 355-365.

25. Nakazato, K., Song, H. and Waga, T. 2006. Effects of dietary apple polyphenol on adipose tissues weights in Wistar rats. Exp Anim 55, 383-389.

26. Nishizawa, N., Sato, D., Ito, Y., Nagasawa, T., Hatakeyama, Y., Choi, M. R., Choi, Y. Y. and Wei, Y. M. 2002. Effects of dietary protein of proso millet on liver injury induced by D-galactosamine in rats. Biosci Biotechnol Biochem 66, 92-96.

27. Nishizawa, N., Shimanuki, S., Fujihashi, H., Watanab, H., Fudamoto, Y. and Nagasawa, T. 1996. Proso millet protein elevates plasma level of high-density lipoprotein: a new food function of proso millet. Biomed Enviran Sci 9, 209-212.

28. Park, D. H., Lee, S. T., Jun, D. Y., Lee, J. Y., Woo, M. H., Kim, K. Y., Seo, M. C., Ko, J. Y., Woo, K. S., Jung, T. W., Kwak, D. Y., Nam, M. H. and Kim, Y. H. 2014. Comparative evaluation of antioxidant activities of ethanol extracts and their solvent fractions obtained from selected miscellaneous cereal grains. J Life Sci 24, 26-38.

29. Park, K. O., Ito, Y., Nagasawa, T., Choi, M. R. and Nishizawa, N. 2008. Effects of dietary Korean proso-millet protein on plasma adiponectin, HDL cholesterol, insulin levels, and gene expression in obese type 2 diabetic mice. Biosci Biotechnol Biochem 72, 2918-2925.

30. Park, M. Y., Kim, J. H. and Park, D. S. 2011. Anti-inflammatory activities of hog millet (Panicum miliaceum L.) in murine macrophages through IRAK-4 signaling. Korean J Food Nutr 24, 268-272.
31. Park, M. Y., Jang, H. H, Kim, J. B., Yoon, H. N., Lee, J. Y., Lee, Y. M., Kim, J. H, and Park, D. S. 2011. Hog millet (Panicum miliaceum L.)-supplemented diet ameliorates hyperlipidemia and hepatic lipid accumulation in C57BL/6J-ob/ob mice. Nutr Res Pract 5, 511-519.

32. Park, M. Y., Seo, D. W., Lee, J. Y., Sung, M. K., Lee, Y. M., Jang, H. H., Choi, H. Y, Kim, J. H. and Park, D. S. 2011. Effects of Panicum miliaceum L. extract on adipogenic transcription factors and fatty acid accumulation in 3T3-L1 adipocytes. Nutr Res Pract 5, 192-197.

33. Rosen, E. D. and MacDougald, O. A. 2006. Adipocyte differentiation from the inside out. Nat Rev Mol Cell Biol 7, 885-896.

34. Sahyoun, N. R., Jacques, P. F., Zhang, X. L., Juan, W. and McKeown, N. M. 2006. Whole-grain intake is inversely associated with the metabolic syndrome and mortality in older adults. Am J Clin Nutr 83, 124-131.

35. Savill, J. and Fadok, V. 2000. Corpse clearance defines the meaning of cell death. Nature 407, 784-788.

36. Shimanuki, S., Nagasawa, T. and Nishizawa, N. 2006. Plasma HDL subfraction levels increase in rats fed proso-millet protein concentrate. Med Sci Monit 12, 221-226.

37. Slavin, J. 2003. Why whole grains are protective: biological mechanisms. Proc Nutr Soc 62, 129-134.

38. Slavin, J. L., Martini, M. C., Jacobs, D. R. Jr. and Marquart, L. 1999. Plausible mechanisms for the protectiveness of whole grains. Am J Clin Nutr 70, 459-463.

39. Sun, X. M., MacFarlane, M., Zhuang, J., Wolf, B. B., Green, D. R. and Cohen, G. M. 1999. Distinct caspase cascades are initiated in receptor-mediated and chemical-induced apoptosis. J Biol Chem 274, 5053-5040.

40. Tamori, Y., Masugi, J., Nishino, N. and Kasuga, M. 2002. Role of peroxisome proliferator-activated receptor-gamma in maintenance of the characteristics of mature 3T3-L1 adipocytes. Diabetes 51, 2045-2055.

41. Urizar, N. L. and Moore, D. D. 2003. GUGULIPID: a natural cholesterol-lowering agent. Annu Rev Nutr 23, 303-313.

42. Visscher, T. L. and Seidell, J. C. 2001. The public health impact of obesity. Annu Rev Public Health 22, 355-75. 


\section{초록 : 기장(Panicum miliaceum)의 마우스 3T3-L1 세포에 대한 에폽토시스 유발 및 지방세포형성 억제 효능}

전도연 ${ }^{1} \cdot$ 이지영 ${ }^{1} \cdot$ 한초롱 $^{1} \cdot$ 김관필 $^{2} \cdot$ 서명철 $^{3} \cdot$ 남민희 $^{4} \cdot$ 김영호 ${ }^{*}$

( ${ }^{1}$ 경북대학교 자연과학대학 생명과학부, ${ }^{2}$ 롯데제 과주식회사, ${ }^{3}$ 농촌진흥청 식량과학원 작물환경과, ${ }^{4}$ 농촌진흥 청 식량과학원 기능성작물부)

항 비만 활성소재를 탐색하기 위하여 국내산 8 종의 잡곡으로부터 $80 \%$ 에탄올 추출물을 확보하여 마우스 3T3-L1 전지방세포에 대한 세포독성을 조사한 결과, 기장이 가장 강한 세포독성을 보였다. 따라서 본 연구에서는 기장 에탄올 추출물을 다시 메칠렌 크로라이드, 에칠아세테이트 및 부탄올로 단계 추출하여 각 유기용매 추출물 을 확보하고 각 추출물의 항 비만 활성소재를 3T3-L1전지방세포의 지방세포로의 분화 억제능으로 조사하였다. 그 결과 기장의 부탄올 추출물은 지방세포 분화 유도기간(6일) 동안 처리하였을 때, 대조구보다 중성지방 축적을 약 $50.3 \%$ 억제하는 것으로 나타나 가장 강한 항비만 활성 분획임을 확인하였다. 이와 같은 기장 부탄올 추출물의 항비만 활성은 지방세포 분화유도인자(C/EBPa와 PPARr)의 초기 발현을 억제하여 전지방세포의 지방세포로의 분화를 억제하고, 나아가 지방대사 관련 유전자(aP2 와LPL)의 발현까지도 저해함을 알았다. 그리고 기장의 부탄 올 추출물은 $25 \mu \mathrm{g} / \mathrm{ml}$ 농도에서는 3T3-L1 전지방세포의 지방세포로의 분화를 저해하지만 $50 \mu \mathrm{g} / \mathrm{ml}$ 농도에서는 3T3-L1 전지방세포의 미토콘드리아 세포막 전위 $(\Delta \psi \mathrm{m})$ 를 변화시키고, caspase-3 활성화와 PARP 분해를 유도하여 세포사멸을 유도하였다. 이와 같은 결과는 기장이 항비만 소재를 가진 우수한 잡곡으로서 비만 관련 질환 예방에 우수한 식소재로 활용할 수 있음을 시사한다. 